\title{
Winning Coalition and Corruption: the Case of Mexico
}

\author{
Liu Menglin \\ Beijing Foreign Studies University, Beijing, 100024
}

Keywords: Corruption, coalition, Mexico

\begin{abstract}
This paper explores the reason for corruption in a country. It discusses the relation between the size of the winning coalition (essential backers) and corruption. The paper uses the methodology of process tracing to analyze the typical case of Mexico corruption before and after its political reform. The conclusion is that as the size of the winning coalition enlarges, there will be less corruption in the country. This paper not only explains corruption from the institutional perspective in two specific dimensions-- the size of the winning coalition and the electorate. It challenges the traditional view of the arbitrary typology of political regimes and provides new insights into a state's politics.
\end{abstract}

\section{Introduction}

Recent years, corruption has attracted increasing attention around the world. In countries advanced or developing, market- oriented or state- planning, large or small, governments run into troubles because of the exposure of corruption and powerful politicians are from time to time facing bribery accusations. However, scholars never reach consensus regarding what contributes to the rampant corruption around the world and why some countries appear to be more corrupt than others?

Before we explore reasons for corruption, we must first be clear about its definition. In this paper, corruption is defined as the use of public office for private gains (Myint 35). In other words, corruption is the use of public position , status or rank by an office taker for the sake of his own private interests. In the light of this definition, cases of corruption would include extortion, fraud, bribery, embezzlement, nepotism, cronyism, encroachment on public assets and wealth for private use and influence peddling.

This thesis would propose that there is a negative relationship between the size of the winning coalition and the occurrence of corruption. In order to prove this point, the paper is divided into the following the parts. First, I would go through existing research on corruption to find the research gap. Then, considering the research gap, I will present my own theoretical frame work so that the current gap can be made up. Before I move on to specific case analysis of Mexico along the timeline of its political reform, there would be case selection to explain why I would choose Mexico to testify this hypothesis. In the end, there would be the conclusion stating that the lager the size of the winning coalition the lesser the domestic corruption.

\section{Literature Review}

Most existing literature exploring causes of corruption and why it differs from nation to nation generally falls into two dimensions, namely the micro level or the individual level and the macro one or the institutional level. The micro level focuses on the psychological factors of one individual which may or may not lead to corruption. Scholars believing in the macro-level reasons for corruption concentrates on how regime types such as democracy and autocracy relates to corruption.

On the micro and individual level, mainly, two theories are dominant. The first one is the public choice theory. The causal mechanism of this theory is that an individual makes a (bounded) rational decision that leads to a predetermined outcome (Graaf 45). The core of literature on public choice lies in that individuals invariably endeavor to maximize their own utility. The individual is usually 
considered to be a rational person who takes bribery when he decides that the benefits of being corrupt outweighs its expected downsides such as the possibility of being exposed and facing criminal charges. This causation is supported by scholars like Rose Ackerman who states that government officials are corrupt for one simple reason: they perceive that the potential benefits of corruption exceed the potential cost (363). Similarly, Klitgaard claims that "if the benefits of corruption minus the probability of being caught times its penalties are greater than the benefits of not being caught, then an individual will rationally choose to be corrupt" (70). Under the influence of public choice theory, many countries undertake a comprehensive reform encompassing criminal and administrative sanctions, looking forward to reduce corruption by austere criminal and justice system. Since the public choice theory focuses on individualistic behavior and calculations over pros and cons rather than groping determinant factors on a general level, its advantage is that it has relatively close focus (Schinkel 11). It is in this respect, however, it takes little heed of the larger societal context. Even if individualistic factors are significant, it fails to explain triggering factors of corruption under certain circumstances. Is there the possibility that an individual changes his calculation results in accordance with different social circumstances?

The second theory is coined as the bad apple theory. Studies in this theory trace the cause of corruption back to faulty human morality which is called the bad apple. In other words, reasons for corruption are deeply rooted in the bad characters of people and their disposition towards committing crimes. The bad apple theory is nowadays prone to criticisms as there is no way to pinpoint whether a person is a moral vice or virtue. As a result, this theory is not as popular as it used to be in the academia. Punch once commented on police corruption that "In the past there was a tendency to think of corruption as a temporary, exceptional 'problem' to be removed by 'surgical' treatment, as it was a malignant cancer, to restore an otherwise healthy agency (metaphor of the bad apple theory)" (317). Conventional wisdom has shifted recently to see corruption as near universal and as forming a permanent concern" (Graaf 52) It is not unusual for us to find the bad apple theory in literature works, either expressed implicitly or explicitly. However, like mentioned above, there is no way to testify it by empirical studies: this hypothesis only remains at the level of being theorized.

On the macro level, the relation between regimes and corruption is fully elaborated. Scholars believe that, unlike autocratic regimes which is the breeding ground for corruption, democratic governments help reduce domestic corruptions. For one thing, democratic governments are held accountable vertically. Politicians in a democracy are, to a certain degree, accountable for their words and actions (Linz and Stepan). Although ordinary citizens in a democracy may not be powerful enough to force elected officials to work completely according to their personal or majority will, they are able to kick those who do not out of office. Therefore universal suffrage and regular elections give the citizens power to "punish" elected government officials (Chowdhury 94). As a result, politicians have to constrain their voracity and combine personal interest with that of the constituents on the grounds that they fear losing election, which is highly possible when corrupt behavior is exposed. By the same token, this electoral competition also incentivizes opposition parties to supervise the party in power. Unveiling of serious corruption imposes reputation damage to the party or person principally concerned, demands public inquiries and accelerates the dismissal of elected bureaucrats and government officials (Osipian 15). By making officials more responsible to the their population, elections in democratic countries encourage officials to take heed of the constituents rather than simply caring about private interests. Some experts also contend that election competition could drive down private rents, personal gains obtained through the process of production that can be misappropriated by individuals since offers of favorable treatment for special interests can be undercut by the opposition party (Myerson 118). To put it simple, access to someone with great power is not as valuable as in an autocratic country. For another, apart from vertical accountability,a democracy is expected to have horizontal accountability. As Rose-Ackerman states, "one principle of liberal democracy is that power in governments should not be vested in a single authority" (85). Power, in a democracy, is divided and balanced among different branches, namely, the executive, the legislative and the judiciary. This system alone does 
not prevent officials from abusing power. However, when efficient checks and balances are in place where each branch of the government is authorized to hold another to account, a system with horizontal accountability is established. Checks and balances system endeavor to make certain that separate state institutions can patrol each other in the citizens' interest (Merkel 129). Logically, checks and balances is a safeguard against corruption since it provides constraints on government power which are necessary to limit the potential for public officials to accumulate personal wealth and carry out unpopular policies (Barro 167). On the contrary, in an autocracy or oligarchy, there are no legal constraints or other institutions to impede the ruling class from acting in accordance with their own will (Saha et al. 293). Furthermore, checks and balances enhance transparency of government actions for clear information about terms of reference of each branch are available for ordinary citizens. As a result, information rents decrease as there is greater transparency. While the electoral system in a democracy helps hold elected officials accountable to their citizens, horizontal accountability and the separation of power allow state institutions to overlook public officials once they assume offices (Rose-Ackerman 55).

However, qualms about accounting for corruption from the macro level never cease. Above all, experts never reach a consensus on definitions for regime types such as democracy, autocracy and monarchy. The result is that the question that "why some autocracies seem to be less corrupt than some democracies" unanswered. Second, the macro-level explanation fails to account for the fact that even among widely acknowledged liberal democracies there is a huge difference in the degree of corruption. In other words, by no means are two democracies the same or alike, nor are any monarchies, autocracies or military juntas. Inevitably, categorical discussions of regime types lead to the construction of arbitrarily drawn boundaries (De Mesquita 12).

\section{Theoretical Framework}

To further contribute to the macro-level explanation for corruption and make up for its existing shortcomings, this paper argues from the institutional level that the size of winning coalition and that of the electorate exerts a huge influence on domestic corruption. More specifically, countries with large winning coalitions are more likely to be less corrupt. Whereas, ordinary people in countries with a small size of winning coalition are prone to the redistribution of their limited wealth to the rich and the powerful.

Some definitions need clarifying first before further elaboration of their relation with corruption. The electorate entails every person that is granted with the legal right to vote and choose their leaders. However the electorates' preference may not directly influence the final outcome. One of the outstanding features for members from the electorate is that they have opportunities of entering the club of the winning coalition, which is defined as a subgroup of the electorate of the sufficient size such that its support provides the leader with real political power over the rest of the electorate as well as those who are disenfranchised by the authority. In other words, members from the winning coalition are powerful enough to have a say over who is going to lead the country and for how long the leader can cling to power. In return for their support, members from the winning coalition are endowed with private benefits in various forms, either political or economic, by the leader.

How can people measure the size of the electorate and that of the winning coalition? Here, I would cite Soviet Union as an example where members of the winning of coalition accounted for no more than $50 \%$ of the electorate. In USSR, the electorate consisted of almost all adult citizens. That is to say, the electorate membership was solely determined by age and nationality or birthplace. The winning coalition in USSR, however, was made up of only a subgroup of the electorate who were not only electorate members but possessed desirable qualities and proficiency, including membership of the Communist Party. Party membership was symbolic of acknowledgment to its beliefs and creeds without which winning coalition membership is not available for an individual. Lenin once defined the Communist Party as the vanguard of the proletariat (De Mesquita 23), which was a rather small group within a large electorate, a group that did not give credits to capitalism but deeply identified itself with democratic centralism. Communist Party membership was deliberately 
made hard to access, on the whole, representing less than ten percent of all citizens and often much less (Smith, 2005). For example, in 1988, it was recorded in a USSR census that Communist Party membership was around 19.5 million against a total population of 281 million. Whoever in the electorate had the chance of entering the winning coalition, but, as a matter of fact, only a few were picked out. The incumbent needed no more than half of the party members to ensure his cling to power, so that although the electorate contained almost all adult citizens, members from the winning coalition accounted for no more than three to five percent of the total population and maybe much less (De Mesquita 36).

Countries with rigged electoral systems, like USSR, invariably come up with some factitious scarcity in special qualities and proficiency, especially in the membership in the single dominant party, hence making sure that party membership is meaningful and valuable. People from the large pool of the electorate are granted with hope to squeeze into the winning-coalition club despite that, in reality, few have been lifted to the winning coalition. As a result, more often than not, countries with rigged electoral systems have a small winning coalition but a large electorate.

However, countries nominally defined as democratic presidential regimes differ from countries with rigged elections regarding the two dimensions. The democratic presidential system is characterized by country-wide suffrage which makes the size of the electorate quite large and the majority ruling which makes that of the winning coalition equal to about half of the electorate.

The whole theory is based upon a prerequisite assumption that winning office is a central goal of each politician (Riker 334). Ruling, unlike common sense, is all about staying power instead of good governance. Coalitions are built to maximize the prospect of winning and retaining office. Political leaders want to maximize their control over policy choices, minimize the price they must pay to their coalition members and build minimal winning coalitions when possible (De Mesquita 6). People may question the universality of this theory. Indeed, the economic development at stake is limited to countries in which there is a central government. For example, countries like Somalia where there are no powerful central authorities but a lot of warlords are not the subjects of this study.

How exactly in a large-coalition polity is corruption reduced and controlled to a certain degree? The possibility for the incumbent to corrupt is dependent on how much is needed to keep the winning coalition loyal. In a large-coalition polity, the cost of buying loyalty of the winning coalition through private goods can be too high to afford. The money at the leaders' disposal will have to be spread thinly. As a result, leaders relying on large winning coalitions are inclined to produce effective public policies to bring welfare to members of the coalition,one of which can be, for example, lowering tax rates. Leaders in a system with large winning coalition need to work hard to provide benefits for their essential backers and are not able to afford skim off resources provided that they wish to survive. On the contrary, when the size of essential backers is small, the leader is capable of buying loyalty from these backers by granting private goods. Under such circumstance, the leader would extract resources from the national wealth to keep the essential backers satisfied and loyal and himself rich at the expense of the welfare of the electorate. As a result, politics with small winning coalitions tend to become corrupt and private-goods-oriented.

In short, the general pattern is that the opportunity for theft of the state's wealth diminishes as the size of the winning coalition increases.

This paper will make several contributions. At this stage, readers may easily relate the size of the winning coalition and the electorate to traditional regime types like democracies and autocracies. I make a conscious effort to depart away from conventional categorical discussions of regimes. The relation between the size of the winning coalition and that of the electorate and regime categories is as helpful as heuristic measurements and devices. However, by no means are two democracies alike, nor are two monarchies or autocracies. Consequently, discussions of regimes by categories result in the arbitrarily and artificially drawn boundaries, which is why people define democracies in so many different ways. The two dimensions I focus on are theoretically more delicately calibrated than vague classifications like democracies, autocracies and so on. Meanwhile, they are able to encompass every regime types that existing literature identifies. Up until now, since little effort has 
been put into quantified study in these two dimensions, it is difficult for us to identify exact numbers of them. However, they are variables that are conceptually continuous instead of ordinal and categorical, which means that they possess both mathematical and conceptual properties which can be useful when generalizing the marginal influences brought by even very small changes of their values in significant political factors. However, traditional typologies of regimes could not achieve this. As a result, the more we get to know about the values of the winning coalition and the electorate, the more we will learn about politics compared with focusing solely on nominal definitions of regimes. Furthermore, while people tend to think a large winning coalition and a large electorate represent democracy, a large winning coalition and electorate, as a matter of fact, do not define democracy in themselves. For instance, the voting regulations in presidentialism and the system of list-voting more intensely indicate the necessity of a much larger minimal size of the winning coalition compared with the single-member district parliamentary system. However, every one of these three political systems are conventionally categorized as equally democratic. Undoubtedly, democracies require a much larger winning coalition than autocracies. It is also true that various forms of democracies produce winning coalitions with different sizes. In this theory, these differences could imply a large variation in the degree of corruption even within the broad category of democracies. Therefore, identifying those two dimensions is of special significance provided that one wants to look closer at how a polity works. Last but not least, democracy is more often than not believed to be the preferred form of governing. People associate it with many favorable characteristics, including freedom of speech and press, legal constraints over leaders, an independent and impartial judiciary, civil liberties and the rule of law. At the same time, readers may challenge the theory proposed in this paper by contending that the rule of law, impartial judiciary, rigorous checks and balances etc can reduce corruption in a country. No doubt that these factors will influence domestic corruption. However, one crucial point needs driving home here is that all the factors mentioned above result from the fact that there is a large winning coalition in the country. Leaders in this country, in order to satisfy a large number of essential backers, are pressured to rule by law and institutionalize fair trial system as they have come to the realization that, unlike their counterparts in small-winning-coalition countries, there is no way they can obtain loyalty from such a large group by granting private benefits. By the same token, despite the fact that the autocracy is not defined as a regime type where there are corrupt bureaucrats and politicians who are indifferent to public welfare, this paper will draw on specific case to indicate that such behavior of politicians in an autocracy is a natural consequence of having a small-size winning coalition. Therefore, it is this theory that provides the fundamental reason for corruption.

\section{Case Selection}

In order to test the proposed theory, this paper picks Mexico as a typical case and applies the method of process tracing in the case study. Above all, it is difficult to explain extremely high corruption rate in Mexico before 2000 by drawing on conventional institutional theory because Mexico, for one thing, it appeared neither fully democratic nor authoritarian(Klesner 478). For another, ever since 1929, Mexico has been conducting elections, which is a symbol of democracy in some experts' minds. However, Mexico did not fit into the theory that democracy drives down domestic corruption. Therefore, conventional wisdom about the relation between democracy and corruption fails. Second, Mexico can be regarded a representative case. It has significant importance in relation to the general problem at stake. In other words, provided that the theory is valid for Mexico, it is valid for many or even all cases. Mexico, long being controlled by one dominant party before the year of 2000, fell into the category of the small-winning-coalition polity. Despite the fact that countries differ in nominal regime types, either autocracy, party state, monarchy or military junta, they all have relatively small size of the winning coalition. Therefore, Mexico before 2000 is typical for countries with small winning coalitions. By the same token, in the aftermath of the political reform, one-party rule has gradually turned into competitive and open presidentialism. That is to say, Mexico made membership of the winning coalition accessible to a lot of individuals who had previously been excluded from political arena. As a result, Mexico can be representative for 
other countries with large winning coalition. Third, there are two other additional advantages by choosing Mexico as a single case. For one thing, Mexico has been experiencing the process of enlarging the size of the winning coalition. Therefore, it is clear for readers to observe how the gradual enlargement of the size of the winning coalition exerts its influence on the degree of corruption in Mexico. As a result, the theory proposed in this paper can be strengthened. For another, compared with choosing two comparative cases, one with a large winning coalition another with a small one, picking only one single case can best control variables and focus only on the change of the size of the winning coalition.

\section{The Case of Mexico}

Ever since 1929 until 2000, one party had been dominant in Mexico, namely, the Institutional Revolutionary Party (PRI), historically called Revolutionary Party. The 2000 presidential election was Mexico's first truly democratic national contest in a century, and the victory of Vicente Fox-- a former Coca-Cola executive running on the ticket of the center-right PAN (the National Action Party)-- put an end to 71 years of oligarchic rule by the PRI (the Institutional Revolutionary Party) (Krauze 54).

\section{Mexico Before 2000}

During the 71-year of authoritarian rule under PRI, Mexico's politics had been confined to a small group of people. In other words, the size of the winning coalition was rather small. According to the Mexico Constitution, Mexico is a "representative, democratic, and federal republic formed by free and sovereign states in all manners which concern their internal governments, but united in a stabilized federation according to the principles of this fundamental law." Federalism is a political form of government that, by decentralizing power, ensures more responsible and responsive attention to social problems, simplifies the administration of public services and stimulates the participation of the citizenry in the conduct of their own governance (Romero 400). However, the reality was a departure from what is described in the Constitution.

On the national level, PRI downsized the winning coalition by rigged elections and power concentration into the executive branch. In the light of the Mexico Constitution, almost every adult in Mexico could exercise their right to vote, under which circumstance there was a large electorate in Mexico. However, PRI, ever since 1929, had successfully kept at bay the emergence of opposition power and competition. Dissidents were ruthlessly silenced in rigged elections, meaning that a group of people with potential power to challenge and pose a threat on the president's survival were physically or politically eliminated. Consequently, compared to liberal democracies where critics were taken heed of, the size of the winning coalition in Mexico was small. Taking advantage of political means first, and then legislative means with the implementation of the 1946 Electorate Law, PRI had been capable of making decisions in terms of who were entitled to participate in politics and how much power they were allowed to possess. To claim more dominance and keep potential opponents out of the election, the deputation of PRI in the congress promulgated an electoral law in 1946 which made it hard-pressed for opposition parties to operate normally and legally. The law required that any party had to have at least 30,000 members. In the meantime, 1,000 or more members should be distributed at least two thirds of the federal entities (states and territories) at any given time (Bolio 136). This law posed a threat on both far-right and far-left parties because it required that individuals in their ranks be listed on party roles so that party could maintain its minimum membership. It also forced the Communist Party in Mexico to underground activities on the grounds that the Communist Party could not meet the demands of the law which inhibited parties from allying with international organizations or cooperating with foreign political parties. Horcasitas once commented that this law had forced an opposition party to be an illegal opposition and regional parties could not meet legal requirements.

With it the main characteristic of the Mexican party system was a system composed of several parties with slight chances of getting substantial shares of power (Morgenstern and Nacif 434). To 
put it in simple words, by no means could PRI in Mexico be effectively opposed by any other parties. From 1946 to 1963, opposition parties in the House of Representative accounted for 4.7\% of all seats on average. During the next 25 years, $17 \%$ seats of the chamber were held by opposition parties. Then, from 1979 to 1990s, the opposition gained $26.3 \%$ of the seats on average (Morgenstern and Nacif 223). These statistics clearly indicate that PRI had absolute control over opposition parties whose power were strictly restricted and impaired by the dominant one. This hegemony was so pronounced that opposition parties were orchestrated and often sustained by successive governments in order to maintain the illusion of pluralism (Mörner 78). Moreover, the 1946 election law also endowed the government and PRI total control over the election process by assigning PRI and government personnel decisive positions in the Federal Electoral Commission (CFE) and by giving the newly established electoral congress, assembled by the two houses of congress, the right to formally confirm results of both presidential and congressional elections. The Secretary of Interior in Mexico was responsible for supervising activities of other parties and dismissing them if they were believed to violate the law. Control over the CFE made certain that even the opposition parties met the all clauses listed in the law for registration, their registration might be delayed or even denied provided that government believed that these parties' direction and creeds were not identical with the precepts of the political constitution of the United Mexican States and in respect to the national institutions it establishes. In short, the electoral law passed in 1946 contributed to the PRI hegemony in Mexican electoral politics by impeding less moderate and outspoken oppositions' chances of competing in the elections. As a result, the scale of the Mexican winning coalition largely shrank.

Once the PRI secured dominance in national politics, the leader of both the party and the state, the Mexican president, concentrated power of PRI itself into the executive branch, hence scaling down the size of the winning coalition once again. As Miguel Romero has commented, "the preponderant presence of the federal executive branch, in general, and the office of the president of the republic, in particular, have emerged in a manner not unlike that evidenced in most of the other federal democracies of the Western world" (401). The status of the executive branch, especially that of the president has reached to the point that, in the light of Cosio Villegas (1972), "the president of the republic now speaks with the definitive voice on all matters of the Mexican society whether federal, local or municipal; political, economic, or cultural” (18). Consequently, being a PRI member does not equal to being a winning-coalition member. PRI members had to be "filtered" to enter the executive branch of the government and the winning coalition umbrella.

Apart from the national-level strategies that kept the size of the winning coalition small, PRI policies in remote areas also downsized the winning coalition. In the aftermath of the national revolution led by PRI, it had assimilated four corporate sectors into its body, namely, labor, peasants, the military and the popular sector, which, on the face of it, was an act of enlarging the winning coalition. PRI had claimed that these assimilated corporate sectors could enjoy autonomy in their own sphere like economic one. In reality, leaders of these assimilated sectors, known as caciques, from the very beginning, imposed authoritarian rule on their members on behalf of PRI through both carrots and sticks. Leaders of these so-called autonomous sectors were responsible to have their population keep loyal to PRI. Whenever somebody did not, the sector leader was granted the power to exclude the person from any political activities. Party committees on the local, state and national level coordinated the four sectors. As a result, PRI needed only to make certain that these sector leaders stick to it rather than took every citizen into consideration. In other words, by such strategy, the size of the winning coalition in Mexico was once again diminished.

Reports of corruption spanned throughout the 71-year reign of the PRI. In the 1950s, Frank Tannenbaum (1951) assailed corruption in Mexico as the "principal impediment" to good governance and economic growth. Lola Romanucci-Ross (1973) stated that "corruption exists at all levels and affects all formalized positions" in the 1970s (69). About ten years later several experts claimed on Contenido, one of the most popular magazines in Mexico, that corruption was the Mexico number one problem. The Mexican population were also aware of rampant domestic corruption. One research conducted in the 1980 s concluded that $70 \%$ of the subjects agreed that 
paying a bribe was necessary when dealing with government officials (Morris 88). In the meantime, only few respondents said that the media reports of Mexican corruption overstated the degree of the practice. The scenario did not fare better in the 1990s. In a survey conducted in 1994, only $12 \%$ of the interviewees expressed their confidence in the police force, the lowest level given among all public institutions (Golden). What's worse, even $48 \%$ of the individuals questioned reported that they have once been extorted by the police.

Facing such widespread corruption, almost every government promised and endeavored every effort (at least it was claimed as such) to combat corruption, launching anti-corruption campaigns. For example, Luis Echeverria, the Mexico president from 1970 to 1976, by publicly declaring corruption as "a cancer of Mexico", purged a dozen of government officials and commenced a series of political, legislative and administrative reforms to abate corruption. As his successor, Jose Lopez Portillo, in the next six years, also jumped on this bandwagon, dealing with corrupt behaviors, especially in his early years in the office. After making the promise of fight against the corruption, he nailed several regulations including the Law of Responsibility which promulgated the government officials' unveiling of their private properties, the strengthening of the public and congressional supervision over the implementation of every policy and the streamlining of complex governmental red tapes. Well into the 1990s, presidents like Carlos Salinas never ceased to pitch a fight against corruption. He imprisoned a patch of corrupt officials from the former administration, cracked down on notorious havens for corruption such as labor unions and promoted transparency in public governing (Morris 110).

It is not difficult to discover that although several decades have passed and every governments launched certain attack on corruption, severe corruption in Mexico had no signs of faring well, which suggests that the deep-seated causes of corruption remained unresolved. Referring back to the theory raised in this article, analysis of corruption in Mexico based on the institutional theory attributes corruption to the small size of the winning coalition in Mexico. Since the size of the winning coalition was rather small under PRI control. In order to maintain and stabilize its power, PRI needed constant and loyal support from the winning coalition. To secure the support, PRI created opportunities for members from the winning coalition to become corrupt and thus gain personal benefits. In this way, members of the winning coalition were satisfied and offered their support for PRI as an exchange.

PRI made opportunities for bureaucrats to penetrate almost all activities in its population's social activities. Therefore, it was unavoidable for ordinary citizens to follow some kind of complicated red tape provided that they want to get things done. Under such circumstance, individuals were prone to the bureaucrats' abuse of power as they had limited and weak institutional protection. This can be evidenced by the unique existence of caciques in Mexico during the course of PRI reign. Generally, a cacique is defined as a local leader "who has total or near total political, economic and social control of a geographical area" (Cornelius 174). A cacique in rural area has invariably been considered as a political conduit who bridges the gap between the national political system and peasant villages (Wolf 231). Caciques, nominally autonomous but, in reality, closely affiliated with PRI, could be defined as members of the winning coalition on the grounds that PRI relied on them to control the remote rural areas. In order to make certain that caciques identified themselves with the party, PRI sought out ways to keep them satisfied. PRI allowed caciques' monopolization on local resources such as agrarian land and seeds. Since caciques possessed absolute control over those resources, they could whoop up the price for seeds and lease fertile agrarian lands to those who could provide better private benefits to them. Similarly, caciques were endowed to monopolize over violence and means for providing security and protection of the community. They had arbitrary say in the courts' ruling process. As a result, they were often bribed to make unjustified decisions. Thanks to PRI's acquiesce that caciques could override other citizens and monopolize on local resources, they had numerous opportunities to earn personal benefits. Normally, family members of caciques were assigned with governmental posts not out of merits but nepotism. As caciques were from time to time rewarded by their posts, they offered loyalty to support PRI. They would cracked on deviate behaviors that were not in accordance with PRI policies. As caciques monopolized 
almost everything in local life, they could deprived deviant farmers of their plowland to make them submissive. Similarly, they were capable of jailing the dissidents directly. Sometimes, even when a cacique was reported to be corrupt to higher bureaucracy and department of justice, officials would turn a blind eye to those flagrant violations of law as they understood that rural stability relied on the cacique (Morris 157). In short, PRI doled out the opportunities for officials to corrupt on purpose in exchange for their support for the party.

Apart from creating chances for local officials to corrupt to win their support, PRI bought off officials directly by lifting loyal ones to higher offices. A Mexican president had meta-constitutional power as having been discussed above. He claimed total control over the the career paths of a large number of politicians and bureaucrats in the absence of an effective system for choosing civil servants despite that certain laws have pinpointed requirements for being a governmental official. Under such circumstance, the president and, as a matter of fact, all superiors of the pyramid could provide higher offices as side payments if some officials were decided to be loyal and correspond to the party interests.

In the light of the definition of corruption mentioned at the beginning of this paper, the existence of cacique system in rural Mexico allows rampant corruption at the local level. Caciques, as discussed above, would extort their populations and take bribery whenever there is a chance, which is a manifestation of using the public offices for private gains. By the same token, presidents' cronyism can be identified as corruption as well.

Thanks to the small size of the winning coalition, Mexican governments never succeeded in anti-corruption campaigns. Furthermore, they never sincerely and adamantly cracked down corrupt behaviors as they needed corruption to consolidate their power.

\section{Mexico after 2000}

The historical win of Vicente Fox from National Action Party (PAN) in Mexican 2000 presidential election witnessed a dramatic change in Mexico's political sphere.

On the national level, there was an essential electoral and political change in Mexico. It encompasses the growing relevance-- once unimportant when the victor was predetermined-- the rising electoral support for opposition parties at the expense of the once hegemonic PRI, and the increasing presence of opposition politicians at all levels of government (Klesner 709). From late 1990s on, the PRI's seats at the congress shrank from the dominant $80 \%$ to $50 \%$. As a result, PRI was deprived of its right to rewrite the constitution in its own interest. PAN, on the contrary, made huge progress in gubernatorial races as it took down Baja California, Chihuahua, Jalisco and Guanajuato. Besides PAN, other opposition parties won control of dozens of Mexican municipal governments, including some of the most advanced cities. Moreover, after Fox secured presidency, unlike his predecessors who concentrated power in their own hands, he constructed a fairly broad political church, incorporating many former ideological opponents of PAN (Wallis 237) into the executive branch. For instance, the Public Accounting Commission in the Chamber of Deputies for the first time ever since its establishment included members of parties other than the ruling one. As the power of opposition parties strengthened in legislative branch and the inclusiveness of the executive branch enhanced, members of the winning coalition were not limited only to PRI membership. Thus, the size of the winning coalition enlarged.

In remote areas, it was not difficult to observe the ever- growing and strengthening power and autonomy of the civil society. There was a vast and speedy proliferation of grassroots and independent organizations. The rise of these grassroots organizations resulted in the diluting of power since these organizations were once incorporated into PRI or outlawed by PRI. For example, members from popular sectors once under the authoritarian control of caciques restarted the Mexico Anti-corruption League, an independent assessment institution once shut down by the government. It exposed governmental scandals, targeting at raising public awareness and pressuring for more controls on corruption. It even convened a National Tribunal for Public Morality, carrying out a mock trial that found a group of top-level government officials guilty of "cheating the country". Among all its achievements, the most significant one was its access to the president's secret account 
for discretionary use such as providing routine rewards and bonuses to officials in the cabinet (Schuler). Organizations as such that had once been marginalized from political arena started to exert influence on public and pressure on the government. Consequently, these organizations were powerful enough to a president's longevity and could be taken as the newly-assimilated winning-coalition members.

With the enlargement of the size of the winning coalition, it was becoming increasingly costly for a leader to cling to power by doling out private goods. Instead, the most effective way of buying their long-term support turned into implementing public policies in order to cater to coalition members. As a result, corruption was greatly reduced while public policies conducive to social and its population's welfare increased in Mexico.

The system of relying on caciques for controlling rural area was rejected under the new governance. Since opposition parties like PAN and Party of Democratic Revolution largely depend on population in rural areas to beat PRI, once PAN was elected into power in 2000, it promulgated the elimination of cacique system under which caciques had numerous power to extract from national wealth to their personal use. To replace it, PAN granted autonomy to regions once under cacique reign to satisfy those newly assimilated members of the winning coalition. The city of Tlajomulco de Zuniga could be cited as a specific example. Before 2000, Tlajomulco de Zuniga had one of the least accountable governments in Mexico (Duncan Tucker). In the light of Cimtra, an independent watchdog coalition, it boasts the most transparent administration recent years. The city government has embarked on programs to encourage public engagement in decision making. Moreover, it has introduced referendum system that allow voters to have a bigger sway over their local policies. For example, the implementation of "participatory budget” allows local citizens to decide how and on what should their taxes be spent. Under such circumstance, the chance that one single individual encroaches on public resources and enjoys immunity from punishment is lowered. A local construction worker named Manuel speaks highly of the current governing administration when being interviewed. He said that the public officials are doing a great job and they are giving out free school equipment and uniforms which is incredible in the past ("Cimtra Creating Accountability”). Thanks to those policies, Tlajomulco de Zuniga administration gained an incredible score of 100 in the report released by Cimtra in 2013 on government transparency.

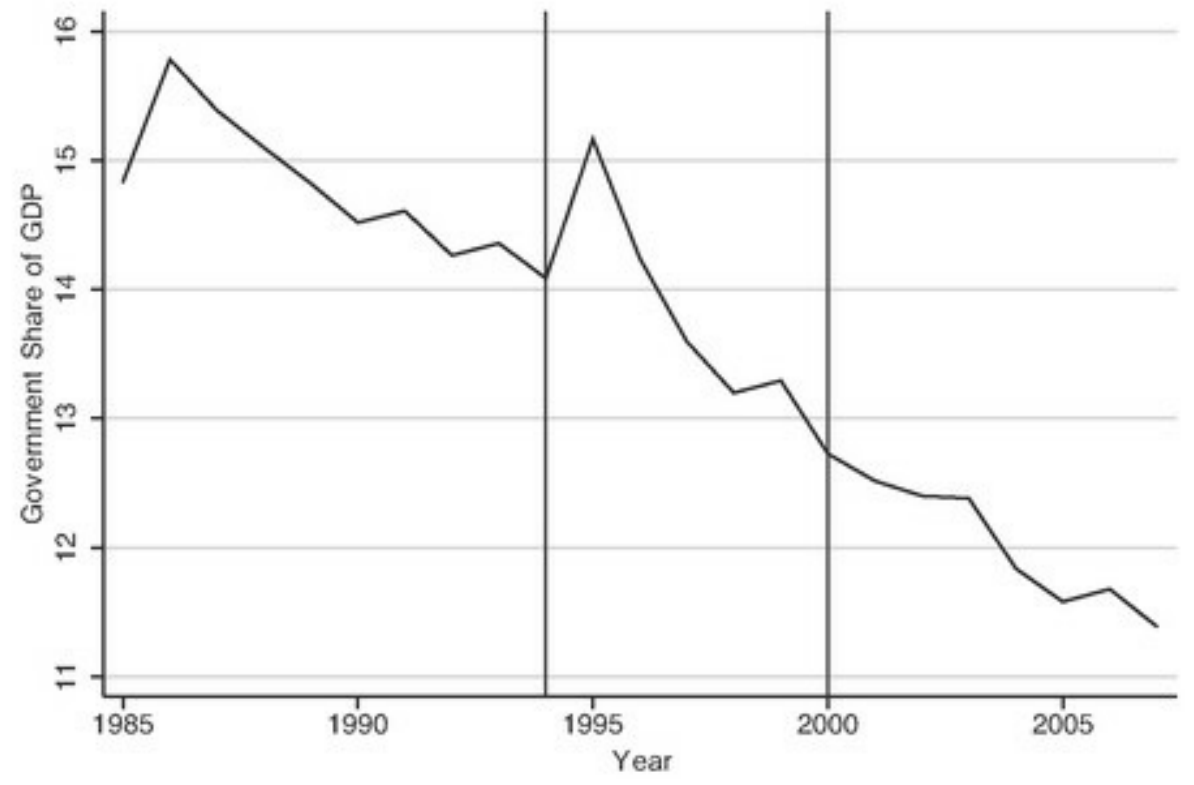

Fig.1

Apart from directly changing the corrupt system into a more transparent and open one, central government under PAN in Mexico introduced a series of public policies that were beneficial to the social welfare. Among all public policies lowering tax rates was met with wide-spread popularity. People are more inclined to keep their hard-earned money to their own pocket. Only when money to be extracted will be pooled to offer something they deem significant but are unable to afford 
individually like fire department and police force, do citizens pay their taxes willingly. Since the uses of tax are so limited in a large-winning-coalition polity, the authority has no option other than lowering it down. Onset of the first competitive and fair election in 1994 and the historical defeat of PRI in 2000 symbolized the commencement of the decrease in the government revenue as a percentage of GDP. The following graph indicates detailed information in terms of how tax rates changed over the years in Mexico (De Mesquita 1068).

As the size of the winning coalition scaled up, Mexican domestic tax rates followed suit by lowering, exactly as they should when politicians in power need curry favor with numerous voters rather than just a few. More specifically, it was when PRI was in firmly control that the highest marginal tax rate of 55\% fell onto the ordinary Mexicans. Until the year of 2000, Mexico's average personal income tax rate was $40 \%$ (De Mesquita 1069). Ever since the unprecedented defeat of PRI, the highest income tax rate for Mexicans was 35\% while the lowest only $28 \%$. Thus, the theory that when the size of the winning coalition enlarges, the government will be less corrupt and more civic-minded is justified by the PAN's fundamental change of political system at regional level and their tax rates reforms.

In all, Mexico, after 2000, ruled out the cacique system in rural areas and substitutes it with autonomous governance, which can be equaled with ruling out a system decayed by corruption. Moreover, as the theory anticipates, Mexico government introduced public policies that are beneficial to the social welfare to satisfy essential backers.

\section{Conclusion}

This paper draws on process tracing and analyzes the case of Mexico before and after the political reform, aiming to explain that the size of winning coalition in a country is the underlying cause of corruption. As the size of the winning coalition shrinks, corruption in a country becomes diffusive and severe and vice versa. The theory in this paper leads us to expect that a large-size winning coalition favors a reduction in the chance for corruption.

Accounting for corruption from two dimensions-- the winning coalition and the electorate-allows us to find out the fundamental and latent reason for corruption and its differences among countries. Conventional explanations for corruption such as the absence of rule of law could all be caused by the small size of the winning coalition in a country. Furthermore, by raising these two dimensions, we call for caution against arbitrary classifications which assign countries with nominal types like democracy, pseudo-democracy, autocracy, oligarchy etc. By no means are there two countries in the world alike or the same. As we label them with those nouns, we are undermining and even deliberately denying their diversities so that problems at hand can be simplified in most cases. However, there are always times when we are supposed to distinguish differences between facially similar countries. Conventional wisdom does work under such circumstance while discussing polity differences from these two dimensions can be helpful.

\section{References}

[1] Barro, Robert J. "Determinants of democracy." Journal of Political economy 107.S6 (1999): 158-83. Print.

[2] Chowdhury, Shyamal K. "The effect of democracy and press freedom on corruption: an empirical test." Economics letters 85.1 (2004): 93-101. Print.

[3] "Cimtra: Creating Accountability in Mexico." Cimtra. org. Mx, 31 December, 2014. Web. 10 July, 2017.

[4] Cornelius, Wayne A. Politics and the migrant poor in Mexico City. Stanford UP, 1975. Print.

[5] Graaf, Gjalt. "Causes of corruption: towards a contextual theory of corruption." Public Administration Quarterly 31.1 (2007): 39-86.

[6] De Mesquita, Bruce Bueno. The logic of political survival. MIT press, 2005. 
[7] Golden, Tim. "Rebels Determined" to Build Socialism." Mexico, New York Times. New York Times, 4 January 1994. Web. 18 June 2017.

[8] Horcasitas, Juan Molinar. "El tiempo de la legitimidad: Elecciones, Autoritarianismo, y Democracia en México." Researchgates, 27 January 1991. Web. 18 June 2017.

[9] Klesner, Joseph L. "An Electoral Route to Democracy? Mexico's Transition in Comparative Perspective." The Journal of Comparative Politics 31.1 (1998): 477-97. Print.

[10] ---. "Democratic Transition? The 1997 Mexican Elections." PS: Political Science \& Politics 30.4 (1997): 703-11. Print.

[11] Krauze, Enrique. "Furthering democracy in Mexico." Foreign Affairs 85.1 (2006): 54. Print.

[12] Linz, Juan J., and Alfred Stepan. Problems of democratic transition and consolidation: Southern Europe, South America, and post-communist Europe. Baltimore: JHU Press, 1996. Print.

[13] Merkel, Ron. "Separation of Powers-A Bulwark for Liberty and a Rights Culture." Saskatchewan Law Review 69 (2006): 129. HeinOnline. Web. 18 June 2017.

[14] Morgenstern, Scott, and Benito Nacif. Legislative politics in latin america. Cambridge: Cambridge UP, 2002. Print.

[15] Morris, Stephen D. Corruption \& politics in contemporary Mexico. Tuscaloosa: Alabama UP, 1991. Print.

[16] Mörner, Magnus. Race and class in Latin America. New York: Columbia UP, 1970. Print.

[17] Myerson, Roger B. "Effectiveness of electoral systems for reducing government corruption: a game-theoretic analysis." Games and Economic Behavior 5.1 (1993): 118-32. Print.

[18] Myint, U. "Corruption: Causes, consequences and cures." Asia pacific development journal 7.2 (2000): 33-58. Print.

[19] Osipian, Ararat L. "Corrupt organizations: modeling educators' misconduct with cellular automata." Computational and Mathematical Organization Theory 19.1 (2013): 1-24. Print.

[20] Paoli Bolio, Francisco José. "Legislación electoral y proceso político, 1917-1982." Las elecciones en México 74(1985): 129-62. Evolución y perspectivas. Web. 18 June 2017.

[21] Punch, Maurice. "Police corruption and its prevention." European Journal on Criminal Policy and Research 8.3 (2000): 301-324. Print.

[22] Riker, William H. The theory of political coalitions. London: Yale UP, 1962. Print.

[23] Romanucci-Ross, Lola. Conflict, violence, and morality in a Mexican village. Wahington: National Press Books, 1973. Print.

[24] Romero, Miguel Acosta. "Mexican Federalism: conception and reality." Public Administration Review 42.5 (1982): 399-404. Jstor. Web. 18 June 2017.

[25] Rose-Ackerman, Susan. "Political corruption and democracy." Connecticut Journal of International Law 14 (1999): 363. HeinOnline. Web. 18 June 2017.

[26] Rose-Ackerman, Susan, and Bonnie J. Palifka. Corruption and government: Causes, consequences, and reform. Cambridge: Cambridge UP, 2016. Print.

[27] Saha, Shrabani, et al. "Democracy and corruption: a complex relationship." Crime, Law and Social Change 61.3 (2014): 287-308. Print.

[28] Schinkel, Willem. "The will to violence." Theoretical Criminology 8.1 (2004): 5-31. Print.

[29] Schuler, Douglas. "Public Sphere Project.” Public Sphere Project, 28 March, 1994. Web. 10 July, 2017. 
[30] Tannenbaum, Frank. A philosophy of labor. New York: Knopf, 1951. Print.

[31] Tucker, Duncan. “Mexico’s New Level of Transparency.” ALJAZEERA, 23 December 2013. Web. 18 June 2017.

[32] Villegas, Daniel Cosío. El sistema político mexicano: las posibilidades de cambio. Mexico City: Joaquín Mortiz, 1972. Print.

[33] Wallis, Darren. "Outfoxing leviathan: campaigning down Mexico way." Journal of Public Affairs 1.3 (2001): 229-238. Print.

[34] Wolf, Eric R. Pathways of power: building an anthropology of the modern world. Berkeley: U of California P, 2001. Print. 